\section{Evaluation of Different Passive Ultrasonic Irrigation Protocols on the Removal of Dentinal Debris from Artificial Grooves}

Rodrigo Ricci Vivan ${ }^{1}$, Jussaro Alves Duque ${ }^{1}$, Murilo Priori Alcalde ${ }^{1}$, Marcus Vinicius Reis Só2, Clóvis Monteiro Bramante', Marco Antonio Hungaro Duarte $^{1}$

\author{
'Department of Operative \\ Dentistry, Endodontics and \\ Dental Materials, Dental School \\ of Bauru, USP - Universidade de \\ São Paulo, Bauru, SP, Brazil \\ ${ }^{2}$ Department of Conservative Dentistry, \\ UFRGS - Universidade Federal Rio \\ Grande do Sul, Porto Alegre, RS, Brazil
}

Correspondence: Rodrigo Ricci Vivan, Alameda Octávio Pinheiro Brisolla, 9-75, 17012-901 Bauru, SP, Brasil. Tel: +55-14-3235-8344. e-mail: rodrigo.vivan@fob.usp.br

\begin{abstract}
The aim of this study was to evaluate the influence of different passive ultrasonic irrigation protocols on the removal of debris in artificially created grooves in the cervical, middle and apical root thirds. Forty extracted bovine incisor roots were instrumented to $1 \mathrm{~mm}$ of the root apex with a R50 Reciproc instrument and irrigated with $2.5 \%$ sodium hypochlorite. The roots were then inserted in a muffle and cleaved into two hemisections. Grooves (3-mm long) were done at 2, 7 and $12 \mathrm{~mm}$ from the root apex in one hemisection and filled with dentinal debris. The hemisections were regrouped into the muffle and divided into 4 groups $(n=10)$ according to the final irrigation protocol: Control group: $3 \times 20 \mathrm{~s}$ using a \#30 gauge needle without agitation of the irrigating solution; Group PUI-s (static passive ultrasonic irrigation): $3 \times 20 \mathrm{~s}$ of passive ultrasonic irrigation with the tip of the insert maintained static on the apical third; Group PUI-t (passive ultrasonic irrigation per third): $20 \mathrm{~s}$ of PUI in each third; Group PUI-d (passive dynamic ultrasonic irrigation): $3 \times 20$ s of PUI dynamically moving the insert in the whole extent of the root canal. In all groups, was used a total of $6 \mathrm{~mL}$ of $2.5 \%$ sodium hypochlorite as irrigant. After these procedures, the grooves were analyzed with a stereomicroscope and assigned scores as regards removal of the debris. The data were analyzed statistically $(\alpha=0.05)$. The results showed a better cleaning in all the groups where the irrigating solution was agitated with ultrasonic device than in the control group $(p<0.05)$. In the apical third, the PUI-d and PUI-s showed similar performance $(p>0.05)$ and a better cleanness than PUI-t $(p<0.05)$. The dynamic and static methods of agitation of the irrigating solution provided more effective cleaning. PUI-d provided the most completely clean grooves suggesting that its use is the most adequate in cases of teeth with complex canal anatomy.
\end{abstract}

Key Words: endodontics, passive ultrasonic irrigation, dentin debris, irrigation.

\section{Introduction}

The anatomy of the root canal system is complex, with areas of irregularities, isthmuses, lateral canals and apical deltas, favoring the presence of microorganisms $(1,2)$ and tissues, as well as the accumulation of dentinal debris after instrumentation (3). Several studies have shown that this accumulation of debris has a negative impact, hampering the correct cleaning and sealing ability of the root canal system (3-5).

Therefore, irrigation has a fundamental role in cleaning these areas, performing physical actions by stirring the irrigant and a chemical action of the irrigant solution (6-8). In addition, Versiani et al (9) observed that in the conventional irrigation method, the irrigant was not able to act on every wall, leaving untouched significant areas, especially in roots with anatomical complexities.

Passive ultrasonic irrigation (PUI) has been described as an excellent auxiliary in the process of final cleaning of root canals (10), increasing the efficiency of irrigant solutions in removing debris, microorganisms and smear layers, especially in areas of anatomical difficulty (10-13).

Several studies made with agitation of the irrigant with ultrasonic tips advise that they be inserted $1 \mathrm{~mm}$ from the working length and perform $3 \times 20 \mathrm{~s}$ agitations, being the most common protocol in Endodontics (14-17). However, these studies used in vitro methodologies with grooves made only in the apical portion of the root canal. But areas of the anatomical complexity, as isthmus, may be present at any extent of the canal $(3,18)$. There is little information in The literature is scarce on data that evaluate whether the dynamic use of the ultrasonic insert (with movement of the tip), or agitation by thirds have similar or better results when the tip remains in a static position, $1 \mathrm{~mm}$ from the working length.

Thus, the aim of the present study was to evaluate by artificial grooves, if passive ultrasonic irrigation (static, dynamic or activated at each thirds) influences the debris removal at the cervical, middle and apical thirds. The null hypothesis was that there is no difference in the method 
of PUI on debris removal from artificial grooves.

\section{Material and Methods}

Forty extracted bovine incisor teeth were used in the study. All the teeth were examined with a magnifying glass to exclude roots with malformation, fractures, resorption and curvatures. In addition, only the roots that presented an initial apical diameter of 40 were used. All crowns were removed with a diamond disc (KG Sorensen, Cotia, SP, Brazil) and the roots were standardized $16 \mathrm{~mm}$ from the apex, using a digital caliper (Starrett Indústria e Comércio Ltda., São Paulo, SP, Brazil). Next, two longitudinal grooves on the external surface of the roots, one in the mesial and distal, were carried out with the same disc, without hitting the root canal.

The samples were molded with condensation silicone (Clonage; DFL, Rio de Janeiro, RJ, Brazil) and inserted into a metal muffle to prevent leakage from the irrigating solution, resulting in a closed system.

The biomechanical preparation was performed with a R50 Reciproc instrument (VDW GmbH, Munich, Germany), the working length was set at $15 \mathrm{~mm}$, which corresponded to the real length of the tooth subtracting $1 \mathrm{~mm}$. A new instrument was used for each root. During the preparation, $2 \mathrm{~mL}$ of $2.5 \%$ sodium hypochlorite $(\mathrm{NaOCl})$ was used as an irrigating solution, which was inserted in the root canal with a $30 \mathrm{G}$ needle (Navitip; Ultradent, UT, USA) attached to a $5 \mathrm{~mL}$ disposable syringe (Ultradent), positioned $2 \mathrm{~mm}$ from the working length.

Next, the samples were removed from the muffle and cleaved in previously made guiding grooves, using a chisel. Three longitudinal grooves ( $3 \mathrm{~mm}$ long, $0.2 \mathrm{~mm}$ wide and $0.3 \mathrm{~mm}$ deep) were made on the internal surface of the root canal in one of the hemisections at 2, 7 and $12 \mathrm{~mm}$ from the apex, obtaining grooves in the cervical, middle and apical thirds, respectively. The methodology of making the grooves was the one used in the study of Martins Justo et al (16).

Debris were obtained by root dentin wear with a \#8 steel round bur (KG Sorensen) at low speed. Debris weighed on an analytical scale (Sertorius AG, Goettingen, Germany) and separated into $0.075 \mathrm{~g}$ portions and packed in an aluminum foil bag. The debris were mixed with $0.3 \mathrm{~mL}$ of $2.5 \%$ sodium hypochlorite. This mixture was inserted into the grooves with an MTA applicator (Angelus, Londrina, $P R$, Brazil), simulating a clinical situation where the debris accumulate in the root canal irregularities resulting from the biomechanical preparation. The excess of debris was removed with a fine microbrush (FGM, Joinville, SC, Brazil), remaining only within the grooves. The hemisection with the grooves was viewed by a stereomicroscope (Stemi 2000 c; Carl Zeiss, Jena, Germany), for confirmation of the correct filling with the debris. Subsequently, the hemisections were grouped and inserted in a muffle.

\section{Ultrasonic Agitation Protocols}

All samples were irrigated with $2 \mathrm{~mL}$ of $2.5 \% \mathrm{NaOCl}$ using a $5 \mathrm{~mL}$ disposable syringe with a \#30 gauge needle positioned $2 \mathrm{~mm}$ from the working length. In the control group, the irrigating solution remained in the canal without agitation for $20 \mathrm{~s}$. Next, a new irrigation with $2.5 \% \mathrm{NaOCl}$ was performed. This process was repeated two more times, totaling $6 \mathrm{~mL}$ and $1 \mathrm{~min}$ of irrigant contact in the root canal. In the experimental groups, the same protocol was followed, differing by the agitation of the irrigating solution that was performed $3 \times 20 \mathrm{~s}$ with the variation of the method of passive ultrasonic irrigation. In PUI-s, the agitation was performed by inserting the ultrasonic tip to $1 \mathrm{~mm}$ from the working length and remained in this position during the agitation. In PUI-t), the agitation was performed by thirds, $20 \mathrm{~s}$ in the apical third, $20 \mathrm{~s}$ in the middle third and $20 \mathrm{~s}$ in the cervical third. In PUI-d, the agitation was performed dynamically, by moving the ultrasonic tip from the apical to the cervical, performing three agitations of $20 \mathrm{~s}$.

In all groups of, an E1 Irrisonic insert (Helse Dental Technology; São Paulo, SP, Brazil) was used, which has a diameter similar to a \#20 K-file type, coupled to an ultrasound unit (Gnatus Equipmentos MédicoOdontologicos Ltda, Ribeirão Preto, SP, Brazil) on power $2(20 \%)$. The insertion of the ultrasonic tip was always toward the larger grooves due to its effectiveness in removing debris, as demonstrated in a previous study (14), but always avoiding contact of the instrument with the walls of the root canal.

\section{Evaluation of Images and Statistical Analysis}

After each irrigation protocol, the hemisections were separated and the grooves were viewed by a stereomicroscope (Stemi 2000 c; Carl Zeiss) and pictures were taken with $30 x$ magnification. The pictures were taken in the same region of the tooth in all 4 protocols, for standardization and subsequent comparison. The debris left in the grooves after the final irrigation protocols have been marked independently by 2 blinded and calibrated dentists, using the following scores: 1 , the groove was empty; 2 , less than $50 \%$ of the groove had debris; 3 , from 50 to $75 \%$ of the groove had debris and 4 , the groove was completely full of debris (Fig. 1) $(14,19)$.

The Kappa test was performed, to verify the agreement between the examiners, which showed a high correlation $95 \%(\mathrm{R}=0.95)$. Differences in scores of debris between the different groups were analyzed using the non-parametric Kruskal-Wallis and Dunn's tests. The analysis of the scores 
of debris in the same group was perfomed using nonparametric Friedman and Dunn's tests. The significance level of 5\% was set for all tests.

\section{Results}

The results of the study are in Table 1. There were no statistically significant differences between the experimental groups in the cervical third. In the groups where PUI was performed, the cervical third was significantly cleaner than the Control group $(p<0.05)$. The same was observed in the middle third, except for the PUI-t group, which had no statistical difference to any group. At the apical third, there was a greater removal of debris in PUI-s and PUI-d groups when compared with the PUI-t and Control groups $(p<0.05)$.

In intra-group analysis, Control, PUI-t and PUI-d groups had no statistically significant differences in relation to the amount of debris in cervical, middle and apical thirds. Only the PUI-s group presented statistically significant difference, with the cervical third presenting a greater amount of debris in relation to the apical third $(p<0.05)$.

Figure 2 presents the analysis of number of grooves in each score according to the studied group, showing that
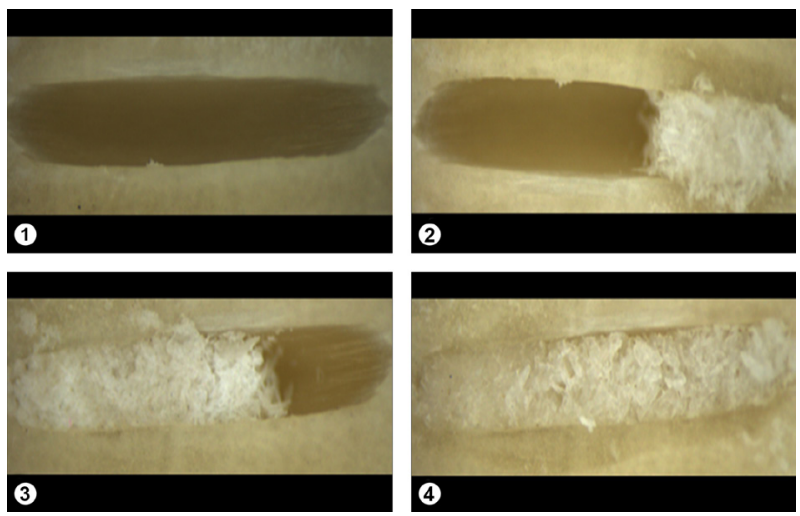

Figure 1. Stereomicroscope images (30x) representing scores: 1, the groove was empty; 2, less than 50\% of the groove with debris; 3 , from 50 to $75 \%$ of the groove with debris and 4, the groove was completely full of debris.

Table 1. Median, Minimum and Maximum of the cleanliness score values of the groups in the different thirds

\begin{tabular}{lcccc}
\hline Third & Control & PUI-s & PUI-t & PUI-d \\
\hline Apical & $4(3-4)^{\mathrm{a}, \mathrm{A}}$ & $1(1-1)^{\mathrm{b}, \mathrm{A}}$ & $2(1-4)^{\mathrm{a}, \mathrm{A}}$ & $1(1-1)^{\mathrm{b}, \mathrm{A}}$ \\
Middle & $4(2-4)^{\mathrm{a}, \mathrm{A}}$ & $1(1-2)^{\mathrm{b}, \mathrm{AB}}$ & $2(1-3)^{\mathrm{a}, \mathrm{A}}$ & $1(1-1)^{\mathrm{b}, \mathrm{A}}$ \\
Cervical & $4(2-4)^{\mathrm{a}, \mathrm{A}}$ & $1.5(1-3)^{\mathrm{b}, \mathrm{B}}$ & $1(1-2)^{\mathrm{b}, \mathrm{A}}$ & $1(1-2)^{\mathrm{b}, \mathrm{A}}$ \\
\hline
\end{tabular}

Lowercase letters indicate statistically significant differences amongst groups in each third $(\mathrm{p}<0.05)$. Uppercase letters indicate statistically significant differences among thirds in each group $(p<0.05)$ the PUI- $d$ group presented a higher number of grooves with score 1 (clean groove) in relation to other groups.

\section{Discussion}

The present study evaluated the ability of debris removal in artificial irregularities made in cervical, middle and apical thirds, depending on different methods of passive ultrasonic irrigation (PUI). According to the results, the tested hypothesis was rejected, since the used protocols showed different results regarding the cleaning of debris inside the grooves.

The used model was similar to that described by Martins Justo et al. (16), but with some modifications to suit the proposed objective of the study.

One of the changes in the model was the making of the grooves not only in the apical third, as was done in most studies $(14,16,19,20)$, but also in the middle and cervical thirds, which are regions of the root canal where large presence of anfractuosities and isthmuses may occur (3).

During biomechanical preparation in molars with isthmuses and irregularities using mechanized instrumentation and conventional irrigation, there is a large amount of debris in the canal and in the areas of isthmus in the whole extent of the canal (18). The accumulation of debris affects penetration of the irrigating solution and root canal dressing to the inside of the isthmus to promote cleaning and antisepsis. Tissue debris and biofilm may remain in these regions, which may produce failure of the treatment $(2,21)$. Debris also occupies the space, thus preventing the complete filling of the root canal by gutta-percha and sealer (5). Therefore, this accumulation of debris will interfere in the antisepsis and the root canal filling, potentially leading to failure of the endodontic treatment $(2,5)$.

Therefore, complete debris removal from the canal lumen and the anatomical complexity areas is fundamental to a better prognosis of the treatment.

Several studies have demonstrated superiority of

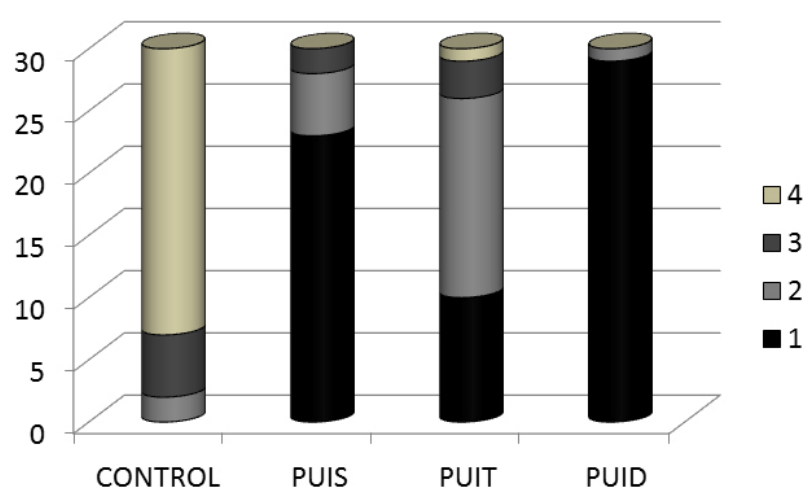

Figure 2. Number of grooves in each score according to the group. 
passive ultrasonic irrigation for debris cleaning in relation to conventional irrigation, advising its use as auxiliary to the debridement process $(11,17,22)$.

The recommendation for the PUI is that the insert be positioned 1 or $2 \mathrm{~mm}$ short of the working length and remain in this position during the agitation of irrigating solution during 3 periods of $20 \mathrm{~s}$ each, with renewal of the irrigant between each agitation (15). Among other effects, ultrasonic insert activation produces a process of acoustic microstreaming along the length of the instrument, cervical to apical, leading to formation of irrigant jets that are directed to the walls of the canal and which are responsible for the removal of debris $(14,23,24)$. In addition, the largest displacement amplitude occurs at the tip of insert (25).

The results of this study showed that the apical third of the PUI-s group produced greater cleaning in the apical groove than in the cervical groove. This probably occurred because of acoustic microstreaming greater in the apical region due to greater agitation amplitude from the tip of the instrument, while the cervical third was the one with lower production of cavitation and consequently worst cleaning. Moreover, despite the statistical analysis showing no difference between the PUI-s and the PUI-d groups, higher percentage of debris removal in the PUI-d group was observed (Fig. 2).

In relation to the group of agitation by thirds, it was observed that in the apical third it had worse results than the other two agitation groups. This occurred probably due the number of agitations, since in this method was made a $20 \mathrm{~s}$ agitation on each third. At the moment the cervical and middle thirds were agitated, the apical third had no agitation since in it the solution moves up to $3 \mathrm{~mm}$ from the tip of the insert $(23,24)$. Therefore, this third only had one agitation of $20 \mathrm{~s}$ and to achieve good cleaning they should be 3 agitations of $20 \mathrm{~s}$, as already observed. Thus, the cumulative effect on apical portion did not occur (15). Maybe a solution would be to carry out agitation for $20 \mathrm{~s}$ on cervical and middle thirds and in the apical third perform 3 agitations of $20 \mathrm{~s}$, requiring future studies for a better elucidation. Furthermore, these findings are similar to those from previous studies $(14,15,23)$ that showed that debris removal was related more closely to the passive ultrasonic irrigation than the conventional irrigation.

In the present study, bovine teeth without curvature were used rather than human teeth in order to obtain sample standardization. The grooves were made in an attempt to simulate areas of anatomical complexity or flatness. The canal of bovine teeth is larger than those of the human teeth in the same way as the artificially prepared grooves compared with isthmuses. Probably, in with less diameter canals and presence of curvature and isthmus, the results can be different due to the difficulty of agitation of the ultrasonic tips. However, the results of the present study can be considered for teeth with straight or flattened root canals.

The agitation of the irrigant with the tip positioned in the apical portion and agitation with the movement of the tip provided a more effective cleaning the grooves than the agitation of irrigant by thirds and conventional irrigation.

\section{Resumo}

0 objetivo deste estudo foi avaliar a influência de diferentes protocolos de irrigação ultrassônica passiva na remoção de detritos em sulcos artificialmente criados nos terços radiculares cervical, médio e apical. Quarenta raizes de incisivos bovinos extraidos foram instrumentadas a $1 \mathrm{~mm}$ do ápice radicular com um instrumento R50 Reciproc e irrigadas com hipoclorito de sódio a 2,5\%. As raizes foram então inseridas numa mufla e clivadas em duas hemisecções. Sulcos ( $3 \mathrm{~mm}$ de comprimento) foram feitos a 2, 7 e $12 \mathrm{~mm}$ do ápice radicular em uma hemiseç̧ão e preenchidos com detritos dentinários. As hemisecções foram reagrupadas na mufla e divididas em 4 grupos $(n=10)$ de acordo com o protocolo de irrigação final: Grupo controle: $3 \times 20$ s usando agulha de calibre \#30 sem agitação da solução irrigadora; Grupo PUI-s (static passive ultrasonic irrigation): $3 \times 20$ s de irrigação ultra-sônica passiva com a ponta do inserto mantida estática no terço apical; Grupo PUI-t (Irrigação ultrassônica passiva por terço): $20 \mathrm{~s}$ de PUI em cada terço; Grupo PUI-d (Irrigação ultrassônica dinâmica): $3 \times 20$ s de PUI movendo dinamicamente o inserto em toda extensão do canal radicular. Em todos os grupos, foi utilizado um total de $6 \mathrm{~mL}$ de hipoclorito de sódio a 2,5\% como irrigante. Após estes procedimentos, os sulcos foram analisadas com um estereomicroscópio e pontuações foram atribuidas quanto à remoção dos detritos. Os dados foram analisados estatisticamente $(\alpha=0.05)$. Os resultados mostraram uma melhor limpeza em todos os grupos onde a solução de irrigação foi agitada com dispositivo ultrassônico do que no grupo controle $(p<0,05)$. No terço apical, o PUI-d e o PUI-s apresentaram performance semelhantes $(p>0,05)$ e melhor limpeza do que o PUI-t $(p<0,05)$. Os métodos dinâmico e estático de agitação da solução de irrigação proporcionaram uma limpeza mais eficaz. 0 PUID promoveu os sulcos mais completamente limpos sugerindo que seu uso é o mais adequado em casos de dentes com anatomia de canal complexa.

\section{Acknowledgements}

This study was financially supported by FAPESP/BRAZIL 2012/06738-9.

\section{References}

1. Ricucci D, Siqueira JF Jr. Fate of the tissue in lateral canals and apical ramifications in response to pathologic conditions and treatment procedures. J Endod 2010;36:1-15.

2. Vera J, Siqueira JF Jr, Ricucci D, Loghin S, Fernández N, Flores B, et al.. One- versus two-visit endodontic treatment of teeth with apical periodontitis: a histobacteriologic study. J Endod 2012;38:1040-1052.

3. Paqué $F$, Laib $A$, Gautschi $H$, Zehnder M. Hard-tissue debris accumulation analysis by high-resolution computed tomography scans. J Endod 2009;35:1044-1047.

4. Haapasalo M, Qian W, Portenier I, Waltimo T. Effects of dentin on the antimicrobial properties of endodontic medicaments. J Endod 2007;33:917-925.

5. De-Deus G, Murad C, Paciornik S, Reis CM, Coutinho-Filho T. The effect of the canal-filled area on the bacterial leakage of oval-shaped canals. Int Endod J 2008;41:183-190.

6. Stewart GG. The importance of chemomechanical preparation of the root canal. Oral Surg Oral Med Oral Pathol 1955;8:993-997.

7. Gutierrez JH, Garcia J. Microscopic and macroscopic investigation on results of mechanical preparation of root canals. Oral Surg Oral Med Oral Pathol 1968;25:108-116.

8. Chow TW. Mechanical effectiveness of root canal irrigation. J Endod 
1983:9:475-479

9. Versiani MA, De-Deus G, Vera J, Souza E, Steier L, Pécora JD, et al.. 3D mapping of the irrigated areas of the root canal space using microcomputed tomography. Clin Oral Investig 2015;19:859-866.

10. Burleson A, Nusstein J, Reader A, Beck $M$. The in vivo evaluation of hand/rotary/ultrasound instrumentation in necrotic, human mandibular molars. J Endod 2007;33:782-787.

11. Gutarts R, Nusstein J, Reader A, Beck M. In vivo debridement efficacy of ultrasonic irrigation following hand rotary instrumentation in human mandibular molars. J Endod 2005;31:166-170.

12. Adcock JM, Sidow SJ, Looney SW, Liu Y, McNally K, Lindsey K, et al.. Histologic evaluation of canal and isthmus debridement efficacies of two different irrigant delivery techniques in a closed system. J Endod 2011;37:544-548.

13. Ribeiro EM, Silva-Sousa $Y T$, Souza-Gabriel AE, Sousa-Neto MD, Lorencetti KT, Silva SR. Debris and smear removal in flattened root canals after use of different irrigant agitation protocols. Microsc Res Tech 2012;75:781-790.

14. Jiang LM, Verhaagen $B$, Versluis $M$, van der Sluis LW. Influence of the oscillation direction of an ultrasonic file on the cleaning efficacy of passive ultrasonic irrigation. J Endod 2010;36:1372-1376.

15. van der Sluis LW, Vogels MP, Verhaagen B, Macedo R, Wesselink PR. Study on the influence of refreshment/activation cycles and irrigants on mechanical cleaning efficiency during ultrasonic activation of the irrigant. J Endod 2010;36:737-740.

16. Martins Justo $A$, Abreu da Rosa $R$, Santini MF, Cardoso Ferreira MB, Pereira JR, Húngaro Duarte MA, et al.. Effectiveness of final irrigant protocols for debris removal from simulated canal irregularities. J Endod 2014;40:2009-2014.

17. Mozo S, Llena C, Chieffi N, Forner L, Ferrari M. Effectiveness of passive ultrasonic irrigation in improving elimination of smear layer and opening dentinal tubules. J Clin Exp Dent 2014;6:47-52.
18. De-Deus G, Marins J, Neves A de A, Reis C, Fidel S, Versiani MA, et al.. Assessing accumulated hard-tissue debris using micro-computed tomography and free software for image processing and analysis. J Endod 2014;40:271-276.

19. Lee SJ, Wu MK, Wesselink PR. The effectiveness of syringe irrigation and ultrasonics to remove debris from simulated irregularities within prepared root canal walls. Int Endod J 2004;37:672-678.

20. Capar ID, Ozcan E, Arslan H, Ertas H, Aydinbelge HA. Effect of different final irrigation methods on the removal of calcium hydroxide from an artificial standardized groove in the apical third of root canals. J Endod 2014;40:451-454.

21. Carr GB, Schwartz RS, Schaudinn C, Gorur A, Costerton JW. Ultrastructural examination of failed molar retreatment with secondary apical periodontitis: an examination of endodontic biofilms in an endodontic retreatment failure. J Endod 2009;35:1303-1309.

22. van der Sluis LW, Versluis M, Wu MK, Wesselink PR. Passive ultrasonic irrigation of the root canal: a review of the literature. Int Endod J 2007;40:415-426.

23. Jiang LM, Verhaagen $B$, Versluis $M$, Langedijk J, Wesselink $P$, van der Sluis LW. The influence of the ultrasonic intensity on the cleaning efficacy of passive ultrasonic irrigation. J Endod 2011;37:688-692.

24. Malki $M$, Verhaagen $B$, Jiang LM, Nehme $W$, Naaman $A$, Versluis $M$, et al.. Irrigant flow beyond the insertion depth of an ultrasonically oscillating file in straight and curved root canals: visualization and cleaning efficacy. J Endod 2012;38:657-661.

25. Ahmad M, Pitt Ford TR, Crum LA. Ultrasonic debridement of root canals: acoustic streaming and its possible role. J Endod 1987;14:490-499.

Received February 16, 2016 Accepted July 25, 2016 